\title{
Associated projectile inferior vena cava wound with subsequent pulmonary artery missile embolization: a case report and literature review
}

\author{
I. Tsema ${ }^{1,2}$, I. Khomenko ${ }^{1}$, Y. Susak ${ }^{2}$, D. Dubenko ${ }^{2}$ \\ ${ }^{1}$ National Military Medical Clinical Center of Ministry of Defense of Ukraine, Kyiv \\ ${ }^{2}$ Bogomolets National Medical University, Kyiv
}

\author{
$\bigotimes$ Prof. Ievgen Tsema: hemorrhoid@ukr.net \\ I. Khomenko, http://orcid.org/0000-0002-5612-2395 \\ I. Tsema, http://orcid.org/0000-0002-1178-7529 \\ Y. Susak, http://orcid.org/0000-0002-5102-485X \\ D. Dubenko, http://orcid.org/0000-0002-3016-0799
}

\begin{abstract}
A rare and unpredictable complication of firearm and missile injuries is projectile embolism. With only a few cases described in the literature, bullet embolism may become a diagnostic challenge for emergency physicians and military surgeons. Bullet embolization is a rare phenomenon, but the complications can be devastating.

CASE PRESENTATION. A 34-year-old man sustained a severe complex abdominoskeletal mine-blast injury with damage to the hollow organs (duodenum and transverse colon), inferior vena cava and both low extremities. The internal hemorrhage was stopped by phleborrhaphy. The wounds of the duodenum and large intestine were sutured, and gunshot fractures of both anticnemions were stabilized by extrafocal osteosynthesis. The wholebody CT showed that there was a projectile embolus into the branch of the right mid-lobe pulmonary artery. No clinical manifestations of pulmonary artery embolism were observed in the patient. After surgery, he developed multiple necrosis and transverse colon perforations that resulted in fecal peritonitis. The suture line leakage that caused the formation of a duodenal fistula and postoperative wound infection were also detected. The complications were managed by multiple reoperations. The attempts of endovascular bullet extraction weren't undertaken due to severe concomitant injuries, complications and asymptomatic clinical course of pulmonary artery projectile embolism. Open surgery retrieval of the embolus was successfully performed on the 80th day after injury. The patient was discharged from the hospital in good condition on the 168th day after the missile wound. Conclusions. Patients with missile wounds and no exit gunshot perforation should be examined using the whole-body CT for determining possible migration of a projectile with the blood flow. Patients with asymptomatic pulmonary artery embolism should be managed nonoperatively. In case of symptomatic pulmonary artery projectile embolism, it is reasonable to consider the possibility of open thoracic surgery.
\end{abstract}

\section{KEYWORDS}

missile wound, inferior vena cava, pulmonary artery, venous missile embolism.

ARTICLE • Received 2021-10-01 • Received in revised form 2021-10-04

() General Surgery, 2021

The hybrid war of Russia against Ukraine has been ongoing in certain districts of Donetsk and Luhansk oblasts within the Donbas area since 2014 and this armed conflict is officially entitled as an antiterroristic operation (ATO) by Ukrainian government [16]. The pro-Russia separatists use various types of weapons against Armed Forces of Ukraine, for instance, artillery, multiple launch rocket systems, and such explosive devices as land mines or improvised explosive devices (IED). The administration of high-energy weapons is associated with severe injury of military personnel, which frequently results in thoraco-abdominal traumas or upper/lower extremity amputations.

A rare complication of combat injuries is arterial or venous embolism caused by bullet or fragmentation of explosive devices, which is described in case report studies $[6,7,10]$. IED fragment embolism 
may be a cause of death due to its association with limb-threatening ischemia, sepsis, endocarditis, cardiac valves insufficiency, pulmonary embolism, and stroke [31]. Furthermore, diagnosis of arterial embolism can be challenging due to the migration of the fragment, rare presentation and diagnostic difficulties.

According to the previously published case reports, X-ray and computed tomography (CT) are used for detection of bullet emboli into blood vessels following gunshot injuries in non-war situations. This type of embolism is rare and may be suspected in patients with perforating injuries or bleeding into the peritoneal/retroperitoneal space. Nevertheless, the possibility of bullet or metal fragment embolism cannot be ignored [14, 23]. The previously published reports suggest the following criteria that indicate a high risk of projectile embolism: the changing shrapnel position in the subsequent X-ray images referred to as «roaming bullet» phenomenon; absence of an exit wound [40]; there are more entrance wounds than exit wounds [10]; the actual location of the embolic metal fragment, as seen on X-ray or CT, that does not correspond with the location of the bullet wound channel [6, $7,23,31]$. If the above-mentioned diagnostic signs are observed in a patient after gunshot injury, the whole-body CT and angiography are justified for specifying a projectile position and evaluation of distal circulation $[7,10,40]$.

The aim of this study was to report a clinical case of a combat patient who was injured in an armed conflict in eastern Ukraine, underwent the wholebody CT scan and was diagnosed with pulmonary artery embolism caused by a fragment after a booby trap explosion. Furthermore, the study was aimed to review the existing data suggested by previously published case reports on the clinical features of blood vessel embolism caused by bullet or projectile fragments.

\section{Case presentation}

On May 30, 2017, a 34-year-old male received a complex abdominoskeletal mine blast trauma at approximately 09:10 am during a combat mission in the area of the battle conflict zone in eastern Ukraine (Donetsk region, Leninske settlement). Aspects of trauma - mine explosion (tripwire trap). Type of trauma - penetrating blind wound of the abdomen with the injury to the colon and duodenum, as well as marginal injury of the inferior vena cava. Multiple gunshot missile wounds of both lower extremities with the gunshot fractures of the tibia and fibula in the upper third of the left shin and in the lower third of the right shin with the displacement of fragments; injury to the right posterior tibial artery. A gunshot missile perforating wound of soft tissues of the right hand.

Medical emergency treatment was provided on the spot by the medical personnel of the unit: a military emergency tourniquet was placed on the right lower extremity; one dose of narcotic pain medication (Butarphanolum $2 \mathrm{mg}$ ), an antibiotic (Doxycycline $100 \mathrm{mg}$ ) and tetanus toxoid (Anatoxin tetanus $0.5 \mathrm{ml}$ ) were administered intramuscularly; aseptic dressing was applied to the wounds of the abdomen and extremities; the transport immobilization of both lower extremities was carried out using the ladder splint. The wounded casualty was urgently evacuated by ambulance to the nearest stage of providing qualified medical assistance.

Qualified surgical treatment was provided in the Central district hospital of Toretsk city, reinforced by specialists in military medicine. The wounded casualty was admitted to the hospital within 55 minutes after injury, according to the principle of the «golden hour». At the time of admission to the stage of qualified surgical care, the patient had absolute signs of a penetrating wound of the abdominal cavity (the dressing was impregnated with intestinal contents and blood) and a clinical picture of the continuing internal bleeding with severe hemorrhagic shock. Consequently, the wounded casualty underwent emergency laparotomy without preoperative preparation. During the operation, there were found out such injuries as: a through and through missile wound of the transverse colon with torn edges, a perforating missile through and through wound of the horizontal part of the duodenum (the 3rd part), a focus of primary traumatic necrosis of the head of the pancreas, diffuse fecal peritonitis in reactive phase; tense retroperitoneal hematoma of large size with severe blood loss (approximate volume of blood loss was $1800 \mathrm{ml}$ ). The disclosure, evacuation and revision of the retroperitoneal hematoma was performed, its source was revealed and included a marginal wound of the infrarenal part of the inferior vena cava. The first stage was placing a vascular suture on the wound of the inferior vena cava to achieve persistent hemostasis. Intensive transfusion of blood preparations (3 doses of erythrocyte mass, 2 doses of fresh frozen plasma) and infusion therapy with colloids and crystalloids were started for arresting the phenomena of severe hemorrhagic shock caused by massive plasmic-blood loss. Taking into account the critical condition of the wounded casualty, the decision to perform minor surgery for small and large intestinal wounds was made. According to the damage-control tactics, the surgical procedure 

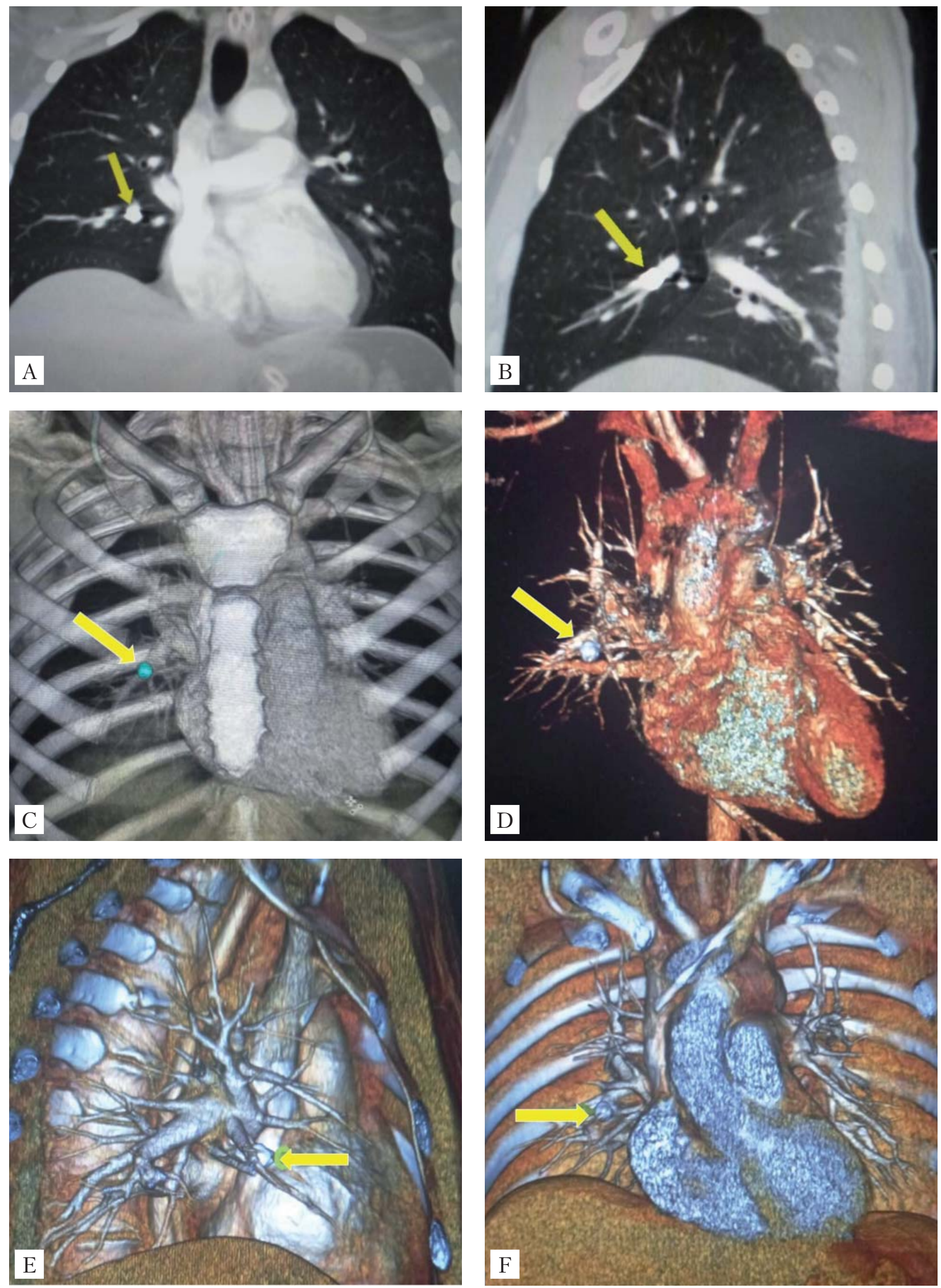

Figure 1. Spiral computed tomography scan of the wounded casualty on the 3rd day after the injury: A, B - frontal and sagittal reconstruction of the image; C - 3D-reconstruction; D - computed tomography angiography; E, F - computed tomography angiography with 3D image reconstruction.

The arrow indicates the location of the missile in the branch of the right mid-lobe pulmonary artery 
included placing a three-row suture on the wound of the transverse colon, placing a double-row suture on the wound of the horizontal part of the duodenum, insertion of nasojejunal tubes, drainage of the abdominal cavity (to the sites of the sutures on the duodenum, inferior vena cava and small pelvis), and laparotomy wound suturing. Resection of necrotic foci in the head of the pancreas was not performed. In order to stabilize the systemic hemodynamics after the abdominal stage of the operation, a 30-minute pause was made for intensive infusion therapy. After stabilization of hemodynamics, operation on the lower extremities was carried out. After removing the military emergency tourniquet, bleeding from the right tibial artery was revealed, but there were no signs of critical limb ischemia. Due to the extremely severe condition of the patient, the multiple nature of the lesions and the absence of signs of critical limb ischemia, and according to the damage-control tactics, a decision was made to perform final hemostasis on the right lower extremity using ligation of the right posterior tibial artery, which is the least traumatic type of surgery. In order to stabilize the sites of gunshot fractures of the bones of the left tibia, extra-focal metalosteosynthesis was performed with a rod external fixation device. As the final evaluation of the right shin viability after ligation of the posterior tibial artery was impossible, metalosteosynthesis on the right limb was not performed. On June 31, 2017 (the 2nd day after injury), the patient was evacuated by air transport to the stage of specialized surgical treatment.
Specialized surgical treatment was provided to the wounded casualty in the Military Medical Clinical Center of the North Region (Kharkiv). Upon admission, the patient underwent ultrasonography of the abdominal and pleural cavities, and the spiral computed tomography (SCT) of the cranial, thoracic and abdominal cavities. According to ultrasonography, the inferior vena cava was not dilated, the blood flow was retained, and there was a small amount of fluid in the right paranephric fatty tissue. According to the SCT, there were no signs of retroperitoneal hematoma; a foreign body of metallic density of $9.5 \times 6.5$ $\mathrm{mm}$ was detected in the branch of the right mid-lobe pulmonary artery (Fig. 1). No wound holes were detected on the chest and the diaphragm, so it was assumed that the missile migrated from the inferior vena cava to the pulmonary artery after surgery. Taking into consideration the absence of clinical manifestations of the pulmonary artery missile embolism, severe patient's condition and the presence of severe combined abdominoskeletal trauma, no attempt of Xray endovascular removal of the missile was made.

Due to the viability of the tissues of the right lower extremity after ligation of the posterior tibial artery on the 2nd day after injury, repeated surgical treatment of the secondary necrosis foci of both extremities was performed and fixation of the bones of the right shin with a rod external fixation device was carried out.

The patient was provided with daily changes of the wound dressing, infusion detoxification, antibacterial therapy (Ceftriaxone $4 \mathrm{~g}$ /day, Metronidazole

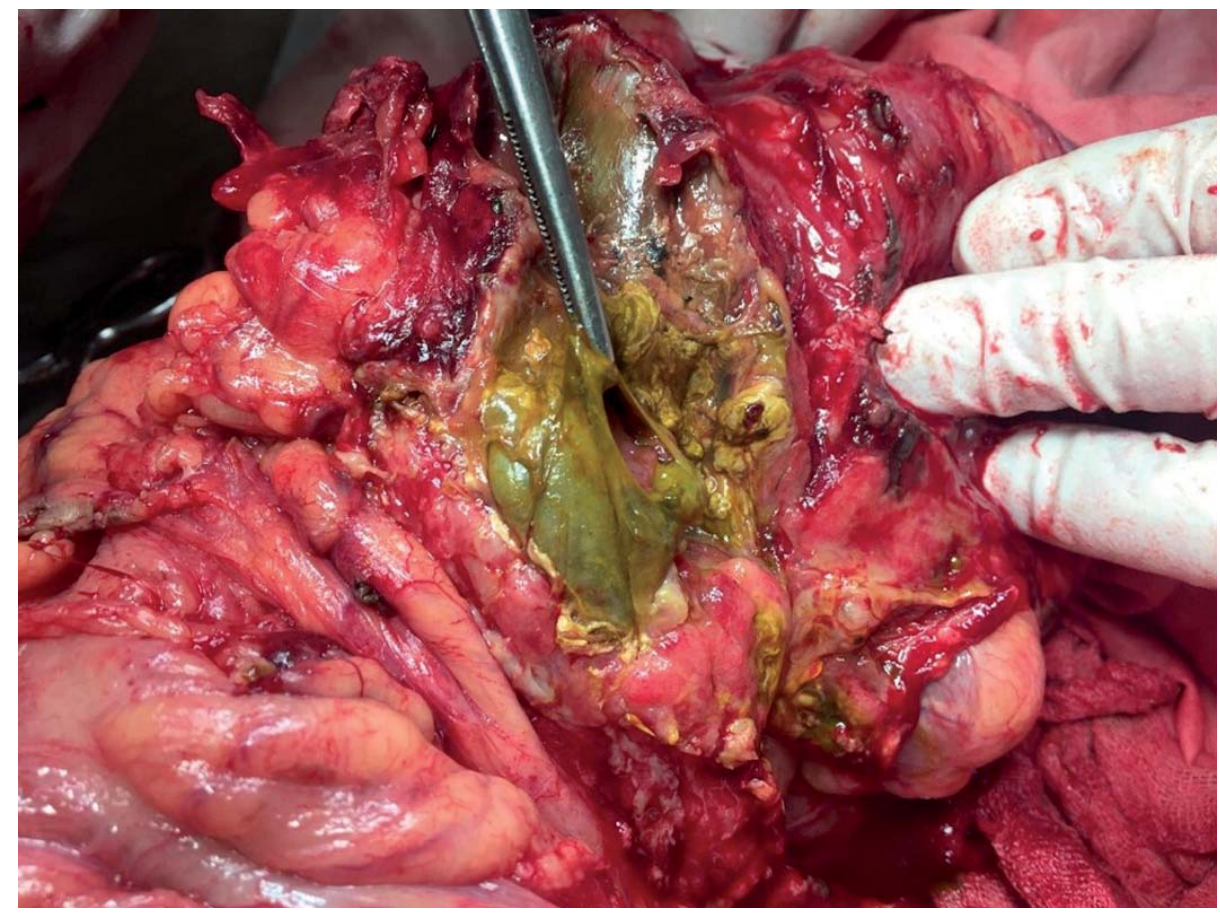

Figure 2. Intraoperative photo on the 9th day after injury. A zone of necrosis and perforation (indicated by an arrow) at the suturing site of the perforating wound of the transverse colon, local limited fecal peritonitis 


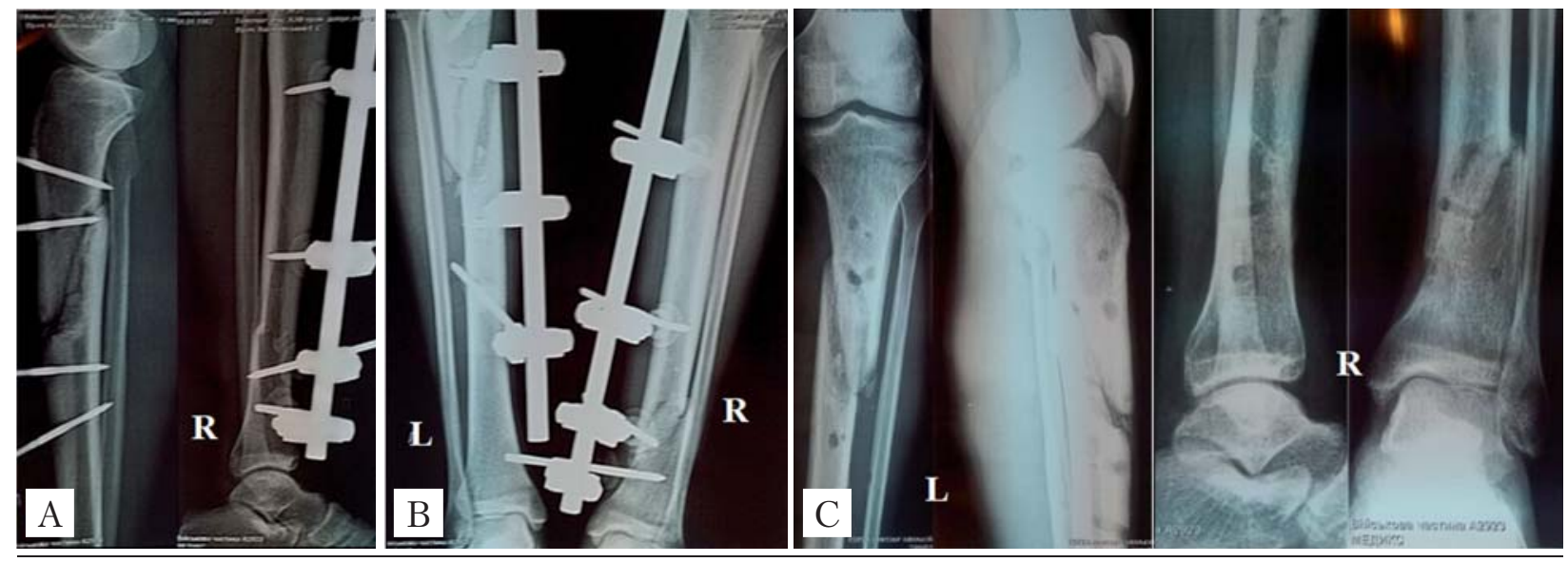

Figure 3. Dynamics of reparation of the gunshot fractures of the bones of the upper third of the left shin and the lower third of the right shin, metal osteosynthesis by rod external fixation devices:

A - the 102nd day after injury; B - the 154th day after injury; C - the 168th day after injury, the external fixation devices were dismantled, and the patient was discharged from the hospital)
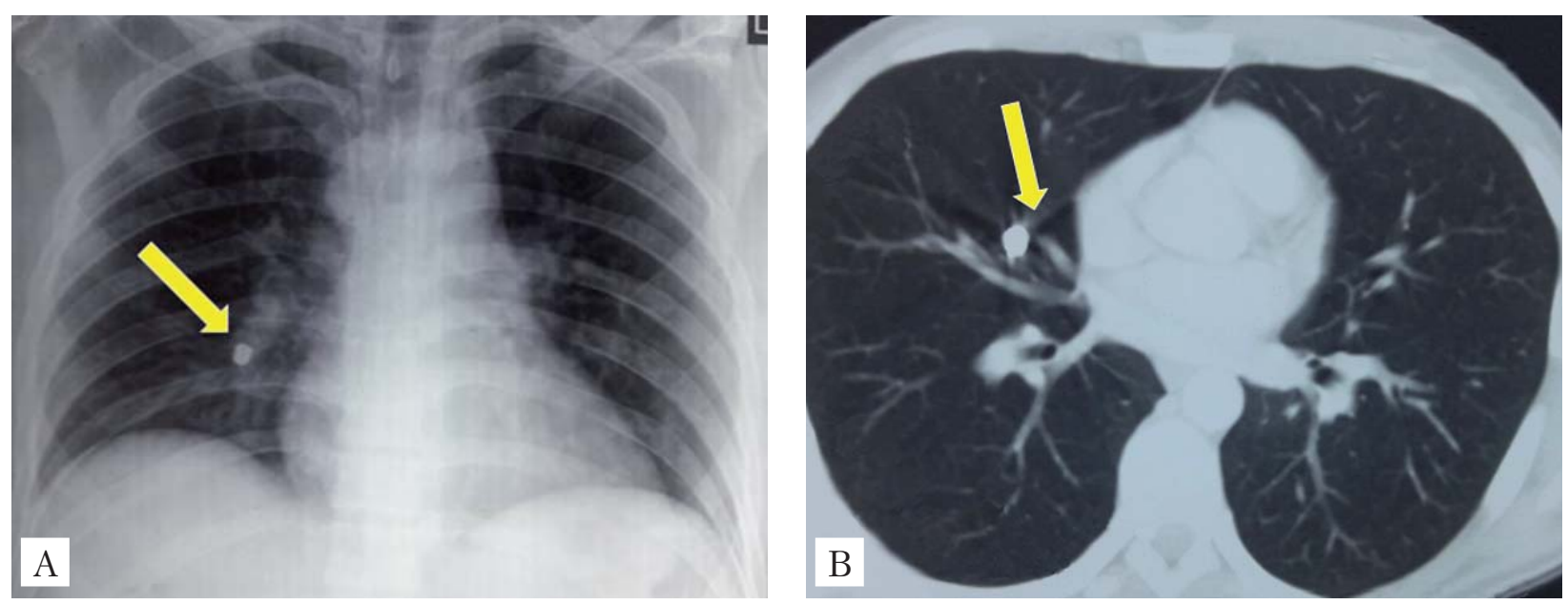

Figure 4. The position of the missile-embolus in the right mid-lobe pulmonary artery on the 63th days after injury: A - chest X-ray; B - SCT of the lungs with axial reconstruction of the image. The arrow indicates the position of the missile

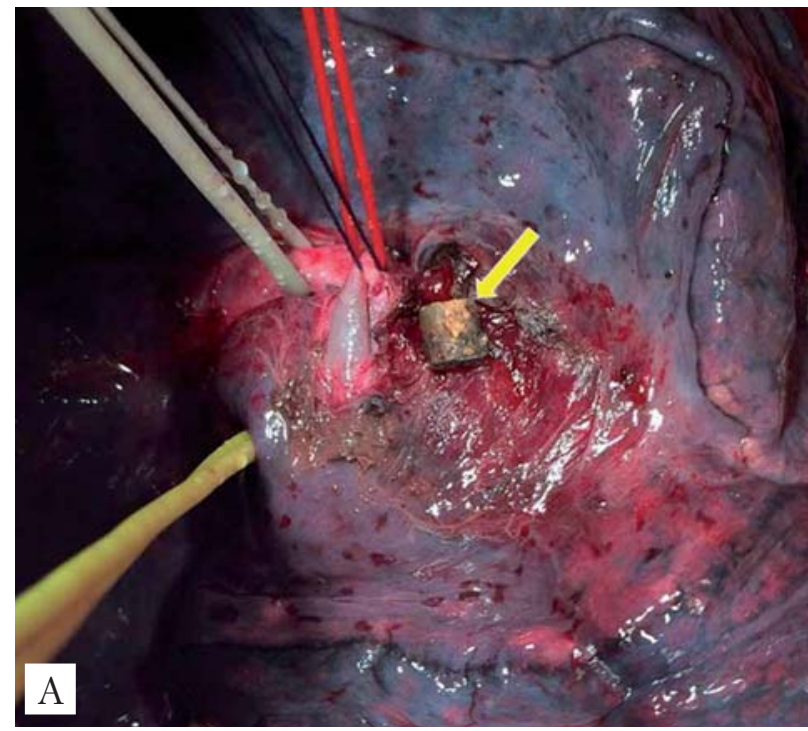

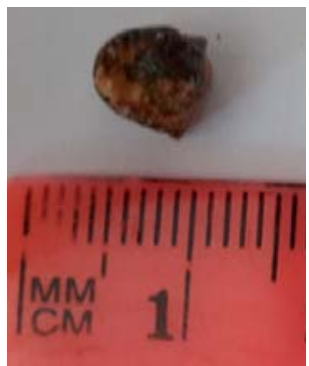

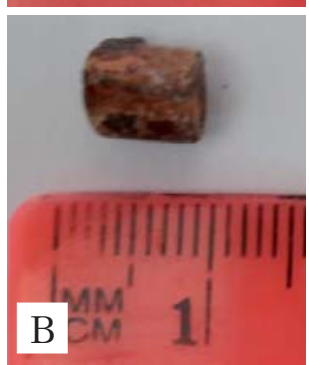

Figure 5. Intraoperative photo of the missileembolus removal from the right mid-lobe pulmonary artery (A), and removed missile-embolus (B). White holder - the trunk of the right pulmonary artery after the origin of the lower-lobe artery; red holder - right mid-lobe pulmonary artery; the dark navy holder is a branch of the right mid-lobe artery to the medial segment (thrombosed); yellow holder - medium-lobe pulmonary vein; the arrow indicates the missile extracted from the lumen of the vessel 
$1 \mathrm{~g} /$ day), parenteral nutrition, supporting medication (Pantoprazole $40 \mathrm{mg} /$ day, Metoclopramide hydrochloride $20 \mathrm{mg}$ /day, Drotaverine hydrochloride $80 \mathrm{mg} /$ day, Enoxaparin sodium $80 \mathrm{mg} /$ day, iron preparations $200 \mathrm{mg} /$ day), transfusion of the same group erythrocyte mass ( 2 doses), fresh-frozen plasma, albumin (20 g/day), infusion and vitamin therapy $\left(\mathrm{B}_{1}, \mathrm{~B}_{12}\right)$, and physiotherapy.

In the course of the treatment, the patient's condition remained severe stable, the wound process on the lower extremities proceeded according to the nature of the primary lesion. On the 3rd day after injury, enteral feeding was started through the inserted nasojejunaltube, and the drains were removed from the suture site of the inferior vena cava and small pelvis.

On the 8th day after injury, bile discharge through the drainage was detected at the suturing site of the horizontal part of the duodenum. The patient underwent SCT of the abdomen with double contrast. In the native phase, contrasts were found in front of the descending part of the duodenum with dimensions of $6 \times 5 \times 6 \mathrm{~mm}$ without clear boundaries (contrast output from the bowel lumen). A limited fluid cluster $(32 \times 38 \times 34 \mathrm{~mm})$ with air bubbles without clear boundaries was found out (intra-abdominal abscess was suspected) in the same region.

On the 9th day after injury, due to the developed complication that required a long-term highly specialized treatment, the patient was transported by car to the National Military Medical Clinical Center of the Ministry of Defense (Kyiv) for further surgical treatment.

On the 9th day after injury, the patient underwent relaparotomy. In the right upper quadrant of the abdominal cavity, an infiltrate was revised. During its separation, about $50 \mathrm{ml}$ of fecal content was released from the perforation zone of the large necrosis areas in the transverse colon $(25 \times 30 \mathrm{~mm}$ and $15 \times 40 \mathrm{~mm}$ ) at the suturing site of the perforating gunshot wound. Necrosis was probably caused by secondary irreversible changes in the zone of molecular shock resulting from the missile wound. After sanation of the fecal content, a partial suture line leak, along with the pancreatic juice and bile outflow, was also revealed (Fig. 2).

Considering the intraoperative findings, the leaking site in the duodenum was sutured; right hemicolectomy and side-to-side ileotransverse anastomosis were performed. Taking into account the presence of local peritonitis, post-traumatic pancreatitis associated with an injury to the pancreatic head, as well as pancreatic necrosis, the decision was made to disconnect the stomach and the sutured zone of the duodenum from the passage of food.
Therefore, anantecolic gastroenteroanastomosis with Braun anastomosis was imposed, machine stitches were placed on the antral part of the stomach, and a feeding tube was inserted into the efferent jejunal loop of Braun anastomosis. For the purpose of biliary decompression, ultrasound-guided transhepatic cholecystostoma was applied in the right upper quadrant. There were 4 drain tubes in the abdominal cavity (right iliac region, small pelvis, suturing site of the duodenum and gastroenteroanastomosis). The laparotomic wound was sutured.

Massive soft tissue wounds of the lower extremities were treated by repeated surgical procedures, accompanied by the installation of a VAC system with its reassembly within 3-4 days and excision of the soft tissues affected by secondary necrosis. On the 5th day after relaparotomy, suppuration of the laparotomic wound occurred and had to be managed by secondary surgical treatment. Furthermore, the post-traumatic and postoperative period was complicated by right-sided upper-lobe nosocomial pneumonia and nonspecific reactive hepatitis, which were corrected with medications.

In the postoperative period, the patient received Doripenem monohydrate $1.5 \mathrm{~g} /$ day, Gatifloxacin $400 \mathrm{mg}$ /day, Fluconazole $100 \mathrm{mg}$ /day, Nadroparin calcium $2850 \mathrm{IU}$, Pantoprazole $40 \mathrm{mg} /$ day, epidural block, enzymes, physiotherapy, and enteral feeding. The bile discharge (daily production of $100-120 \mathrm{ml}$ ) was noted as a consequence of the repeated suture line leak at the site of the duodenum on the 2nd day after relaparotomy, and an external duodenal fistula formed. Due to the gastric disconnection and biliary decompression via the cholecystostoma, the volume of the discharge from the duodenal fistula gradually decreased. On the 18th day after imposition of the gastroenteroanastomosis, bile outflow from the fistula was $40-50 \mathrm{ml}$, the drainage tube was removed, and the fistula healed on the 29th day after the duodenum was disconnected from the food passage.

On the 52nd day after injury, the patient was transferred to the stage of rehabilitation treatment as his general condition was satisfactory.

Rehabilitation treatment was conducted in the Military Medical Clinical Center of Occupational Pathology of Personnel (Irpin). The patient was prescribed and provided with physiotherapy, exercise therapy, massage, change of dressings, and symptomatic medications for multi-fragment gunshot fractures of both shins. There was observed a sluggish course of the bone callus formation at the fracture sites (Fig. 3A, B).

Due to the fact that the presence of a missile in the right mid-lobe pulmonary artery had no clinical 
manifestations and the patient suffered from bullous lung disease of the upper lobe of the same lung, the decision was made to perform open thoracic surgery after the completion of the rehabilitation course. 2.5 months after injury, the possibility of endovascular projectile extraction was not considered as the fragment was firmly lodged in the vessel wall. In addition, the patient had an indication for resection of the same lung due to the diagnosed bullous lung disease with a high risk of spontaneous pneumothorax.

The patient was transferred to the clinic of thoracic surgery of the National Military Medical Clinical Center (Kyiv), where the preoperative examination was performed. According to the results of chest X-ray and computed tomography, the position of the missile-embolus in the right mid-lobe pulmonary artery did not change (Fig. 4).

On the 80th day after injury, the patient underwent right-sided thoracotomy in the 5th intercostal space. During palpation of the right lung, a dense foreign body, measuring approximately $10 \mathrm{~mm}$ in diameter, was revealed in the basal region of the middle lobe. The mediastinal pleura was incised, the branches of the right upper pulmonary vein were identified, the right pulmonary artery and the mid-lobe artery were taken by the holders (Fig. 5A). During further examination, a foreign body was detected in the lumen of the branch of the right mid-lobe artery of the medial segment (immediately after the bifurcation of the lobar artery). Above the foreign body, the wall of the vessel was opened and a metal missile with dimensions of $8 \times 6 \mathrm{~mm}$ (Fig. $5 B$ ) was discovered. It lodged firmly in the vessel wall (the form of the missile-embolus was similar to a piece of metal wire, which is used in the production of anti-personnel mines for the maximum crippling effect). The distal lumen of the artery was thrombosed, whereas the blood supply to the middle lobe of the right lung and its aeration were preserved due to the collateral blood flow. The missile bed was washed with antiseptic; the proximal and distal ends of the vessel were ligated. An atypical resection of the upper lobe of the right lung was performed in response to the presence of the bulls up to $15 \mathrm{~mm}$ in the upper lobe of the right lung.

The postoperative period was uneventful. Ciprofloxacin (600 mg/day), ertapenem (1g/day), amikacin sulfate $(1 \mathrm{~g} /$ day $)$ were administered. The patient was provided with change of dressings, physiotherapy, and exercise therapy. The patient was transferred to the stage of rehabilitation treatment. Bone fractures of both extremities were consolidated, external fixation devices were dismantled on the 168th day after injury (Fig. $3 C$ ). The patient was discharged from the hospital in a satisfactory condition and then he was medically retired from the military service.

\section{Discussion}

History. The first case of intravascular foreign body emboli in a 10-year-old boy was reported by Thomas Davis in 1834, and describes venous embolization of a wooden projectile to the right ventricle $[10,22,41]$. The incidence of bullet embolization is very low, with fewer than 200 cases reported $[6,7$, 10,26]. With the exception of an institutional series of 28 cases presented by Mattox et al. in 1979 [22], almost all cases are presented as single case reports.

Epidemiology. A review of 7500 gunshot wounds during the Vietnam War demonstrated a $0.3 \%$ incidence of bullet embolism [10, 22, 31]. The incidence of missile embolization after penetrating injury was reported to be $1.1 \%$ in the Afghanistan and Iraq Wars (of 346 casualties surveyed) [2, 31, 33]. The incidence of bullet embolization in the civilian setting is unknown, but it could be higher because of the lower velocity weapons with lower kinetic energy found in the civilian setting [31].

Pathogenesis. The scenario for a bullet embolism is set up when a low-velocity projectile contains the amount of kinetic energy enough for the initial tissue penetration so that it may traverse only one wall of a vessel, and then gets trapped within the lumen. Commonly, a bullet embolism occurs mostly with $[1,3,7,40]$ :

- small-caliber guns;

- relatively low-powered projectiles, such as BB guns [7], and airgun pellets [4];

- shotgun ammunition, which scatters multiple small metallic pellets.

- According to the clinical reports, the following conditions, which influence the migration of an intravascular foreign body, can be marked:

- missile size [10];

- hydrostatic pressure from blood flow [1, 7, 27];

- gravity [1,27];

- patient body position [10,27];

- vascular anatomy [7, 40];

- muscular and respiratory movement $[1,10]$.

In the presented case report, a soldier suffered from a missile wound with an injury to the inferior vena cava caused by a projectile. The projectile was a piece of a metal wire, which is usually used for additional filling of anti-personnel landmines to achieve the maximum crippling effect and invalidization of those who fall into a tripwire trap. The cylindrical shape of the projectile caused a complete obturation of the pulmonary vein branch and led to its thrombosis. The missile embolism became possible in the presented case because the projectile lost a great amount of its initial kinetic energy while passing through the anterior abdominal wall and the walls of the large intestine and duodenum. Finally, the shrapnel broke 
through one wall of the inferior vena cava and got into the blood flow. In the available literature, we haven't found the cases of missile pulmonary embolism resulting from a mine-blast injury. In the majority of the described cases, the projectile-embolus didn't pass with the bloodstream further than the right ventricle because it was delayed within the tricuspid valve cusps and tendon chords, or the bulletembolus retrogradely moved against the blood flow $[1,8,26]$. About half of the projectile-emboli fall into the right ventricle, $1 / 3$ - into the pulmonary artery, and the rest - into the hepatic vein, inferior vena cava, popliteal, femoral and common iliac vein [26].

Classification. Depending on the nature of the vessel into which the bullet-embolus falls, the missile embolism is divided into arterial embolism and venous embolism [7, 10,31]. Overall, approximately $75-80 \%$ of reported cases are arterial, embolizing to the periphery, and $20-25 \%$ of cases are venous $[1,3,4,6,10,26]$. Arterial embolization most often occurs in the lower extremities, more commonly in the left side than in the right side [6].

The review of case reports showed that venous embolism was caused by primary injuries of the following veins:

- external iliac vein $[6,21,43]$;

- inferior vena cava [23, 31];

- portal vein [18];

- renal vein [22];

- femoral vein [10];

- right ventricle of the heart [14];

- cranial venous sinus $[7,9,12,13,30]$;

- subclavian vein [28];

- neck veins [31, 42].

Depending on the pattern of the venous projectile-embolus movement after falling into the blood flow, the next scenarios of bullet-embolus migration can be distinguished:

- antegrade venous embolism - a bullet-embolus migrates with the blood flow towards the right ventricle of the heart; in cases of passage through the tricuspid valve, a missile-embolus gets to the pulmonary artery $[7,10,23,43]$;

- retrograde venous embolism - a bullet-embolus moves against the blood flow under the influence of gravity in the distal direction from the location of the vein injury [3, 35, 25];

- paradoxical embolism - a shrapnel-embolus gets into the bloodstream and reaches the right side of the heart, and then through the arteriovenous fistula or perforation of the atrioventricular septum, or ventricular defect, gets through the patent oval foramen and falls into the arterial bed causing arterial embolism (venous-arterial paradoxical embolism); the cases of the arteriovenous paradoxical embolism have also been described [5, 8, 22, 24, 27, 29, 36, 41];

- «roaming» venous embolism - a projectileembolus is alternately displaced within the venous bed back and forth: in the direction to the heart (along the blood flow) and then in the direction from the heart (against to the blood flow) [10, 31]; sometimes, a bullet-embolus can migrate into the contralateral eponymous vein on the other side of the injured vein [6].

Retrograde venous embolism is extremely rare, with only 14 cases presented in the literature [3, 6]. Retrograde venous embolization occurs in up to $15 \%$ of patients, and the effect of gravity has been suggested as a cause [31].

Depending on the time of the bullet-embolus migration, the following types of venous embolism can be distinguished:

- acute venous embolism, developing immediately or on the first day after injury during evacuation of an injured person [6, 10, 31, 43];

- tardive venous embolism, developing within months or years after injury (there is a case report of the venous tardive missile embolism that developed 14 years after injury $[3,22]$.

Clinical presentation. Arterial and paradoxical emboli typically migrate peripherally to the extremity and present early with limb or end-organ ischemia [6, 10, 31]. Bullet embolization into the arterial system is generally symptomatic in $80 \%$ of patients and is usually discovered early [25, 31].

Venous bullet embolization, however, is asymptomatic in approximately $70 \%$ of patients $[3,6,25]$. However, missile pulmonary emboli may present clinically with many of the same vital findings that one would suspect in case of thromboembolic pulmonary embolism, including tachycardia, tachypnea, hypoxemia [23], dyspnea, chest pain, hemoptysis [15, 35, 40]. Symptomatic patients with venous embolization may present late, sometimes within months or years after the initial injury [5, 20, 22, 25, 26, 37].

Complications. Potential sequelae of missile venous emboli include delayed embolization to the heart or pulmonary vasculature, arrhythmia, valvular dysfunction, sepsis [6], vascular occlusion with pulmonary infarction, [7, 39], pulmonary abscess, erosion in the bronchus [8], pulmonary gangrene, erosion through the arterial wall and subsequent hemorrhage [15, 23, 41], endocarditis, venous thrombosis, thrombophlebitis, severe hypoxia [31], and death $(6 \%)$ [37, 40]. F. L. Shannon et al. reviewed 102 cases of venous bullet emboli from 1930 to 1987 and reported a $25 \%$ overall complication rate [37].

Diagnostic clues. Due to its relative rarity, the possibility of a missile pulmonary embolism isn't 
given much consideration when evaluating trauma CTs for complications, such as viscus perforating injuries or free bleeding into the peritoneal/retroperitoneal spaces. Nevertheless, this possibility should not be ignored [23]. Taking into consideration the existing reports of bullet-embolism cases, it is reasonable to define the following diagnostic clues that help define the risks of projectile embolism:

- the changing shrapnel position as seen in the subsequent $\mathrm{X}$-ray images - «roaming bullet» phenomenon [6, 26, 31];

- the presence of entrance perforation but the absence of exit perforation [7, 40];

- the number of entrance bullet holes is larger than the number of exit bullet holes [10];

- the actual location of the fragment according to the X-ray or CT data doesn't correspond with the position of the bullet wound tract [40].

If the above-mentioned diagnostic signs are observed in patient after gunshot injury, the wholebody CT and angiography are justified for specifying a projectile position and evaluation of the distal circulation $[7,10,40]$.

Management. The treatment of bullet embolization depends on the location of the bullet and partly on the presence or absence of symptoms [6]. Due to the developed ischemia, most arterial emboli cause immediate symptoms that require emergency surgical intervention [6-8, 26, 27]. Generally, most authors agree that arterial bullet emboli should be retrieved as soon as they are recognized [31].

Asymptomatic venous bullet embolization has historically provoked debates over the need for its removal, but the management guidelines haven't been clearly established $[3,7,10,23]$. The treatment planning often depends on whether or not the patient is symptomatic: in a symptomatic patient, embolectomy is often pursued, whereas in an asymptomatic patient, some still advocate embolectomy [38, 40], while others promote more conservative measures, such as supportive care [17, 22 , 32]. F. L. Shannon reported that about $25 \%$ of patients would suffer eventual morbidity from venous embolization, and the author recommends a mandatory extraction in the acute setting [37]. Whereas, J. B. Kortbeek reported a series of 32 cases of bullet embolism to the pulmonary artery, 14 of which were managed non-operatively. None of the non-operatively managed patients for whom follow-up data were available suffered an adverse effect from the embolus [17]. As reported by some authors, the right ventricular bullet emboli could be observed if the bullet was less than $5 \mathrm{~mm}$, firmly lodged, with no evidence of arrhythmia or valvular dysfunction [27].
Endovascular treatment. The first report of endovascular retrieval of a bullet, performed by G. O. Hartzler in 1980, describes retrieval of a bullet from the right ventricle using a snare device [6, 11]. This was perfected by S. J. Sclafani in 1991, who recommended the application of the balloon occlusion of the proximal vein to prevent procedure-related central embolization [34]. While the number of reported cases remains small, recent publications report growing use and success of endovascular retrieval [26, 29]. So, endovascular extraction should be the first-line treatment of symptomatic cases of pulmonary bullet emboli when feasible [10]. Some authors recommend pulmonary embolectomy in asymptomatic patients only if the bullet is accessible via an endovascular approach, even in the absence of symptoms, to prevent delayed complications [26].

Both successful and unsuccessful cases of endovascular extraction of projectiles are described in the literature. For example, C. O. Carter described a case of successful endovascular retrieval of a bullet from the left external iliac vein using percutaneous angiographic bullet extraction [6]. Whereas, T. Nolan reported about multiple unsuccessful attempts of endovascular extraction of a bullet-embolus from the retrohepatic inferior vena cava; in 2 weeks, the bullet-embolus accidentally migrated to the common iliac vein, from where it was successfully removed by an endovascular method [31]. We didn't find any reports of successful cases of primary endovascular retrieval of a projectile-embolus from the pulmonary artery due to the technical difficulties of this procedure. Thereby, M. G. Yamanari reported about multiple unsuccessful attempts of bullet retrieval from the lingular segment of the left pulmonary artery [43].

G. G. Fernandez-Ranvier described several attempts of right internal iliac vein laser embolization and inferior vena cava filter placement to prevent a venous missile embolism. However, all these attempts were unsuccessful and a bullet-embolus migrated to the pulmonary artery [10].

Review of 45 cases of venous bullet emboli from 1987 to 2010 revealed 14 of 45 patients ( $31 \%$ ) were managed successfully without extraction [26]; 26 cases $(58 \%)$ were managed by surgical intervention. Some authors were in favor of extraction of the missile in all patients with intracardiac missiles and of observation in selected asymptomatic patients with pulmonary arterial emboli $[26,31]$.

In the presented case, we didn't try to perform endovascular extraction of a projectile from the pulmonary artery because the patient had an associated severe abdomino-orthopedic mine-blast injury with gunshot damage of the hollow body 
organs (duodenum and transverse colon) and inferior vena cava. These complex injuries required multiple urgent surgical interventions to manage comorbid damages of the duodenum and transverse colon, as well as complications of these injuries. Furthermore, the patient didn't have any clinical manifestations or complications of pulmonary artery missile embolism. F. L. Shannon advises the same management of the case, even if more than 6 weeks have passed after injury [37].

Open surgery. Surgical intervention should be considered when endovascular procedures fail [10]. A review of 17 patients with bullet emboli in the pulmonary arteries found that seven out of nine patients died when embolectomy wasn't performed, compared to no deaths in eight patients who underwent surgical embolectomy [39].

We consider open surgery an optimal method for surgical treatment of patients with projectile pulmonary artery embolism who were injured more than 2 months ago. The fragment lodges firmly in the vessel wall over time, which is one of the causes of unsuccessful endovascular extraction of a bullet. The video endoscopy is used for a bullet extraction in the clinics with technologically advanced equipment for video-assisted thoracic surgery which is operated by experienced and specially trained surgeons. We didn't consider this type of surgical procedure due to lack of experience in performing such operations.

The substantial risk of surgery, involving the pulmonary artery, and even endovascular intervention within the artery, must be carefully weighed so as to avoid potential long-term embolus-related complications in each particular clinical case [28].

Complex wound. It should be noted that in the majority of cases, shrapnel venous embolism resulted from a single gunshot vascular injury. In the literature, we found only three clinical reports of venous bullet embolism caused by magistral vessel wound associated with a gunshot injury of the internal organs: 2 cases of magistral vein wound associated with a terminal ileum injury [6] and 1 case of a through and through injury to the liver, small intestinal injury at two locations, and a single injury to the infrarenal vena cava [31]. An overview of the previously published clinical reports showed that the cases of associated abdomino-orthopedic wound with an inferior vena cava injury complicated by venous missile embolization of the pulmonary artery were not described in the scientific literature. Lack of the information on this issue makes our study original and novel. The presence of concomitant internal injuries can significantly change the above-described management of patients with projectile venous embolism. It was to some extent outlined based on the analysis of almost 200 cases of missile embolism. First of all, the damage-control tactics and the concept of «golden hour» must be applied to wounded patients, including their evacuation to the hospital stage of surgical care within 60 minutes [16]. Further accumulation of experience in the management of missile embolism in patients with severe associated injuries of the internal organs will allow developing guidelines for the treatment of these patients.

\section{Conclusions}

Major vein gunshot wounds can be associated with bullet penetration into a vein lumen and its further migration to the right side of the heart and pulmonary artery. Patients with a missile wound and no exit gunshot perforation should be examined using the whole-body CT for determining possible migration of a projectile with the blood flow. Patients with asymptomatic pulmonary artery embolism should be managed non-operatively as all attempts of endovascular extraction of a bullet are usually unsuccessful. In case of symptomatic pulmonary artery projectile embolism, it is reasonable to consider the possibility of open thoracic surgery.

\section{DECLARATION OF INTERESTS}

The authors declare that they have no competing interests. Funding. The study received no funding.

\section{ETHICS APPROVAL AND WRITTEN INFORMED CONSENTS STATEMENTS}

The study was approved by the ethical committee at Bogomolets National Medical University and written informed consent to participate in the study was obtained.

\section{AUTHOR CONTRIBUTIONS}

I. Tsema: acquisition of data, analysis and interpretation of data, drafting of manuscript; I. Khomenko: study conception and design, acquisition of data, drafting of manuscript; Y. Susak: study conception, critical revision of manuscript, D. Dubenko: analysis and interpretation of data, drafting of manuscript.

\section{REFERENCES}

1. Agarwal SK, Singh A, Kathuria M, Ghosh PK. Wandering bullet embolizing to the pulmonary artery: a case report. Asian Cardiovasc Thoracic Ann. 2007;15(2):154-6. DOI: $10.1177 / 021849230701500215$.

2. Aidinian G, Fox CJ, Rasmussen TE, Gillespie DL. Varied presentations of missile emboli in military combat. J Vasc Surg. 2010;51(1):214-7. DOI: 10.1016/j.jvs.2009.06.054.

3. Bertoldo U, Enrichens F, Comba A, Ghiselli G, Vaccarisi S, Ferraris $\mathrm{M}$. Retrograde venous bullet embolism: a rare occurrence case report and literature review. JTrauma. 2004;57(1):187-92. DOI: 10.1097/01.ta.0000135490.10227.5c 
4. Colquhoun IW, Jamieson MP, Pollock JC. Venous bullet embolism: a complication of airgun pellet injuries. Scott Med J. 1991;36(1):16-7. DOI: 10.1177/003693309103600107.

5. Corbett H, Paulsen EK, Smith RS, Carman CG. Paradoxical bullet embolus from the vena cava: a case report. J Trauma. 2003;55(5):979-81. DOI: 10.1097/01.TA.0000028835.94166.68.

6. Carter CO, Havens JM, Robinson WP, Menard MT, Gates JD Venous bullet embolism and subsequent endovascular retrieval - A case report and review of the literature. Int J Surg Case Rep. 2012;3(12):581-3. DOI: 10.1016/j.ijscr.2012.06.011.

7. Duke E, Peterson AA, Erly WK. Migrating bullet: A case of a bullet embolism to the pulmonary artery with secondary pulmonary infarction after gunshot wound to the left globe. J Emerg Trauma Shock. 2014;7(1):38-40. DOI: 10.4103/0974-2700.125638.

8. Ezberci F, Kargi H. Surgical management of a pulmonary artery missile embolism after an air rifle wound to the liver. South Med J. 1999;92(12):1207-9. DOI: 10.1097/00007611-19991200000015 .

9. Goldman RL, Carmody RF. Foreign body pulmonary embolism originating from a gunshot wound to the head. J Trauma. 1984;24(3):277-9. DOI: 10.1097/00005373-198403000-00018.

10. Fernandez-Ranvier GG, Mehta P, Zaid U, Singh K, Barry M, Mahmoud A. Pulmonary artery bullet embolism - Case report and reviewюInt J Surg Case Rep. 2013;4(5):521-3. DOI: 10.1016/j. ijscr.2013.02.017.

11. Hartzler GO. Percutaneous transvenous removal of a bullet embolus to the right ventricle. J Thorac Cardiovasc Surg 1980;80(1):153-5.

12. Hiebert CA Gregory FJ. Bullet embolism from the head to the heart. JAMA. 1974;229(4):442-3.

13. Hughes BD, Vender JR. Delayed lead pulmonary emboli after a gunshot wound to the head. Case report. J Neurosurg. 2006;105(3 Suppl):233-4. DOI: 10.3171/ped.2006.105.3.233.

14. Jackson CC, Munyikwa M, Bacha EA, Statter MB, Starr JP. Cardiac BB gun injury with missile embolus to the lung. J Trauma. 2007;63(4):100-4. DOI: 10.1097/TA.0b013e3181469ea7.

15. John LC, Edmondson SJ. Bullet pulmonary embolus and the role of surgery. Thorac Cardiovasc Surg. 1991;39(6):386-8. DOI 10.1055/s-2007-1020007.

16. Khomenko I, Shapovalov V, Tsema I, et al. Hydrodynamic rupture of liver in combat patient: a case of successful application of "damage control» tactic in area of the hybrid war in East Ukraine Surg Case Rep. 2017:3(1):88. DOI: 10.1186/s40792-017-03636DOI: 10.1097/00005373-199212000-00020.

17. Kortbeek JB, Clark JA, Carraway RC. Conservative management of a pulmonary artery bullet embolism: case report and review of the literature. J Trauma. 1992;33(6):906-8. DOI: 10.1097/00005373-199212000-00020

18. Layton TR, Stroh AM, Villella ER. Missile embolus of the portal vein. J Trauma. 1985;25(11):1111-2.

19. Lichte P, Oberbeck R, Binnebösel M, Pape HC, Kobbe P. A civilian perspective on ballistic trauma and gunshot injuries. Scand J Trauma Resusc Emerg Med. 2010 Jun 17;18:35. DOI: $10.1186 / 1757-7241-18-35$

20. Lundy JB, Johnson EK, Seery JM, Pham T, Frizzi JD, Chasen AB. Conservative management of retained cardiac missiles: case report and literature review. J Surg Educ. 2009;66(4):228-35. DOI: 10.1016/j.jsurg.2009.04.002.

21. Marshall CD, Ma MR, Park J, et al. Recovery of a missile embolus from the right ventricle. Ann Thorac Surg. 2017;103(1):69-71 DOI: 10.1016/j.athoracsur.2016.06.107.

22. Mattox KL, Beall AC Jr, Ennix CL, DeBakey ME. Intravascular migratory bullets. Am JSurg. 1979;137(2):192-5. DOI: 10.1016/0002-9610(79)90143-0.

23. Mctyre E, McGill L, Miller N. Missile pulmonary embolus secondary to abdominal gunshot wound. Radiol Case Rep. 2012;7(3):709. DOI: 10.2484/rcr.v7i3.709.

24. Meeks T, Nwomeh B, Abdessalam S, Groner J.Paradoxical missile embolus to the right superficial femoral artery following gunshot wound to the liver: a case report. J Trauma. 2004;57(6):1338-40. DOI: 10.1097/01.ta.0000152311.84257.4d.

25. Michelassi F, Pietrabissa A, Ferrari M, Mosca F, Vargish T,

Moosa HH. Bullet emboli to the systemic and venous circulation. Surgery. 1990;107(3):239-45.
26. Miller KR, Benns MV, Sciarretta JD, et al. The evolving management of venous bullet emboli: a case series and literature review. Injury. 2011;42(5):441-6. DOI: 10.1016/j.injury.2010.08.006.

27. Nagy KK, Massad M, Fildes J, Reyes H. Missile embolization revisited: a rationale for selective management. American Surgeon. 1994;60(12):975-9.

28. Nally L, Kahn SA, Jacobs I, Johnson MS, Bankey PE. Pulmonary artery missile embolus after a gunshot wound to the upper extremity. J Trauma Acute Care Surg. 2012;72(3):111. DOI: 10.1097/TA.0b013e3182198bce.

29. Nazir Z, Esufali ST, Rao NS, Rizvi I. Venous bullet embolism: a case report and review of the literature. Injury. 1992;23(8):561-3. DOI: 10.1016/0020-1383(92)90163-m.

30. Nehme AE. Intracranial bullet migrating to pulmonary artery. J Trauma. 1980;20(4):344-6.

31. Nolan T, Phan H, Hardy AH, Khanna P, Dong P. Bullet embolization: multidisciplinary approach by interventional radiology and surgery. Semin Intervent Radiol. 2012;29(3):192-6. doi: 10.1055/ s-0032-1326928.

32. Patten ED, Morales HE. Bullet emboli to the pulmonary artery: a rare occurrence. J Trauma. 1982;22(9):801-2. DOI: 10.1097/00005373-198209000-00016.

33. Rich NM, Collins GJ Jr, Andersen CA, McDonald PT, Kozloff L, Ricotta JJ. Missile emboli. J Trauma. 1978;18(4):236-9. DOI: 10.1097/00005373-197804000-00002.

34. Sclafani SJ, Shatzkes D, Scalea T. The removal of intravascular bullets by interventional radiology: the prevention of central migration by balloon occlusion - case report. J Trauma. 199:31(10):1423-5. DOI: 10.1097/00005373-199110000-00022.

35. Schmelzer V, Mendez-Picon G, Gervin AS. Case report: transthoracic retrograde venous bullet embolization. J Trauma. 1989;29(4):525-7. DOI: 10.1097/00005373-198904000-00021.

36. Schurr M, McCord S, Croce M. Paradoxical bullet embolism: case report and literature review. J Trauma. 1996;40(6):1034-6. DOI: 10.1097/00005373-199606000-00034.

37. Shannon FL, McCroskey BL, Moore EE, Moore FA. Venous bullet embolism: rationale for mandatory extraction. J Trauma. 1987;27(10):1118-2.

38. Singer RL, Dangleben DA, Salim A, et al. Missile embolism to the pulmonary artery: case report and pitfalls of management. Ann Thorac Surg. 2003;76(5):1722-5. DOI: 10.1016/s00034975(03)00692-1.

39. Stephenson LW, Workman RB, Aldrete JS, Karp RB. Bullet emboli to the pulmonary artery: a report of 2 patients and review of the literature. Annals of Thoracic Surgery. 1976;21(4):333-6. DOI: 10.1016/s0003-4975(10)64322-6.

40. Symbas PN, Harlaftis N. Bullet emboli in the pulmonary and systemic arteries. Ann Surg. 1977;185(3):318-20. DOI: 10.1097/00000658-197703000-00012.

41. Unkle D, Shaikh KA. Iliac vein to pulmonary artery missile embolus: case report and review of the literature. Heart and Lung. $1988 ; 17(4): 363-5$.

42. Vanarsdell GS, Razzouk AJ, Fandrich BL, Shakudo M, Schmidt CA Bullet fragment venous embolus to the heart: case report. J Trauma. 1991;31(1):137-9. DOI: 10.1097/00005373-19910100000027.

43. Yamanari MG, Mansur MC, Kay FU, Silverio PR, Jayanthi SK, Funari MB. Bullet embolism of pulmonary artery: a case report. Radiol Bras. 2014;47(2):128-30. DOI: 10.1590/S0100 39842014000200018 


\title{
Поєднане поранення нижньої порожнистої вени з уламковою емболією легеневої артерії: клінічне спостереження та огляд літератури
}

\author{
С. Цема ${ }^{1,2}$, І. Хоменко ${ }^{1}$, Я. Сусак ${ }^{2}$, Д. Дубенко ${ }^{2}$ \\ ${ }^{1}$ Національний військово-медичний клінічний центр Міністерства Оборони України, Київ \\ ${ }^{2}$ Національний медичний університет імені О. О. Богомольця, Київ
}

Кульова емболія легеневої артерії - це рідкісне та непередбачуване ускладнення вогнепальних та мінновибухових поранень. Діагностика кульової емболії залишається значним лікувально-діагностичним викликом як для невідкладних, так і для військових хірургів. У літературі трапляються поодинокі повідомлення про таке ускладнення вогнепальних поранень і немає жодних системних спостережень цієї патології. Незважаючи на те, що кульова емболія є рідкісним клінічним феноменом, його наслідки можуть бути катастрофічними для життя та здоров'я пораненого.

Клінічне спостереження. Чоловік віком 34 років отримав тяжке поєднане скелетно-абдомінальне мінно-вибухове поранення з вогнепальними пораненнями внутрішніх органів (дванадцятипала і поперечна ободова кишка), нижньої порожнистої вени та обох нижніх кінцівок. Масивна заочеревинна кровотеча 3 нижньої порожнистої вени зупинена крайовим ушиванням судини неперервним швом. Проведено первинну хірургічну обробку поранень дванадцятипалої та товстої кишок з первинним ушиванням ранових дефектів. Множинні багатоуламкові переломи нижніх кінцівок стабілізовані за допомогою апаратів зовнішньої фіксації. 3 огляду на наявність множинного багатоуламкового вогнепального поранення пацієнтові проведено комп'ютерну томографію всього тіла, за результатами якої в правій середній дольовій гілці легеневої артерії виявлено фіксований уламок-ембол. У ранній післятравматичний період у пораненого не було жодних клінічних виявів кульової емболії легеневої артерії, а тяжкість його стану була зумовлена поєднаною множинної торако-абдомінальною травмою. В післятравматичний період у хворого виникла низка ускладнень: множинні некрози та перфорації поперечної ободової кишки, що спричинили каловий перитоніт, неспроможність швів дванадцятипалої кишки, що призвело до формування зовнішньої дуоденальної нориці, множинні рани м'яких тканин нижніх кінцівок ускладнилися рановою інфекцією. Зазначені ускладнення потребували проведення етапних хірургічних втручань. Після стабілізації стану хворого спроб ендоваскулярної ретракції уламка-ембола з легеневої артерії не здійснювали через наявність тяжких поєднаних скелетно-абдомінальних поранень, їх ускладнення та безсимптомний перебіг кульової емболії легеневої артерії. Успішне видалення уламка-ембола проведено на 80-ту добу після поранення: виконано торакотомію, видалення уламка із середньої дольової артерії, накладено судинний шов, через відсутність явищ склерозу чи інфаркту легені резекції легеневої паренхіми не проводили. Паціента у задовільному стані виписано зі стаціонару на 168-му добу після мінно-вибухового поранення для амбулаторної психосоматичної реабілітації.

Висновки. Пацієнтам зі сліпими множинними уламковими проникаючими вогнепальними пораненнями показано проведення комп'ютерної томографії всього тіла для виявлення потенційної внутрішньосудинної міграції уламків з током крові. У пацієнтів із безсимптомною кульовою емболією видалення уламка-ембола може бути відстрочене до завершення хірургічного лікування провідного поранення та його ускладнень. При розвитку клінічних виявів кульової емболії легеневої артерії доцільно розглянути можливість виконання відкритої торакальної операції.

Ключові слова: уламкове поранення, нижня порожниста вена, легенева артерія, венозний кульовий емболізм.

\footnotetext{
F O R C I T A T I O N

I Tsema I, Khomenko I, Susak Y, Dubenko D. Associated projectile inferior vena cava wound with subsequent pulmonary artery missile embolization: a case report and literature review. General Surgery (Ukraine). 2021:1;48-59. http://doi.org/10.30978/GS-2021-1-48.
} 